\title{
Novel immunotherapies for adult patients with B-lineage acute lymphoblastic leukemia
}

\author{
Guoqing Wei, Jiasheng Wang, He Huang and Yanmin Zhao*
}

\begin{abstract}
The past decade witnessed the rapid development of adult B-lineage acute lymphoblastic leukemia (ALL) treatment. Beyond the development of chemotherapy regimens, immunotherapy is starting a new era with unprecedented complete remission (CR) rate. Targeting B-lineage-specific surface markers such as CD19, CD20, CD22, or CD52, immunotherapy has been demonstrating promising clinical results. Among the immunotherapeutic methods, naked monoclonal antibodies (mAbs), antibody-drug conjugate (ADC), bispecific T cell engager (BiTE), and chimeric antigen receptor (CAR) T cells are the main types. In this review, we will examine the emerging preclinical and clinical development on (1) anti-CD20 naked mAbs rituximab, ofatumumab, and obinutuzumab; (2) anti-CD19 ADCs SAR3419 and SGN-CD19A and anti-CD19 BiTE blinatumomab; (3) anti-CD22 naked mAb epratuzumab and anti-CD22 ADC inotuzumab ozogamicin; (4) anti-CD52 naked mAb alemtuzumab; and (5) anti-CD19 CAR T cells. We will discuss their efficacy, adverse effects, as well as future development.
\end{abstract}

\section{Background}

For children with B cell acute lymphoblastic leukemia (B ALL), current chemotherapy regimens can achieve longterm overall survival (OS) of $80-90 \%$. However, similar results have not been seen in adults. Despite a high initial complete response (CR) rate of $80-90 \%$, most of the adults will eventually relapse with chemotherapyresistant disease. Long-term OS in adults with B ALL remains in the range of $30-50 \%$; the prognosis of relapsed or refractory (R/R) ALL is even more dismal with a 5 -year OS of only $10 \%[1,2]$. For R/R ALL patients, the only option to achieve long-term survival is allogeneic hematopoietic stem cell transplantation (allo-HSCT), which requires reinduction chemotherapy prior to the transplantation. The chemotherapy in the context, however, is generally poorly tolerated with unsatisfied outcomes, as only 5 to $10 \%$ patients can be bridged to allo-HSCT [3]. Although a few new cytotoxic drugs have been approved over the last decade such as clofarabine and liposomal vincristine, the low single-agent response rates (17\% with clofarabine monotherapy, $20 \%$

\footnotetext{
* Correspondence: zjzhaoyanmin@163.com

Bone Marrow Transplantation Center, The First Affiliated Hospital, School of Medicine, Zhejiang University, Hangzhou 310000, China
}

with liposomal vincristine monotherapy) still emphasize an urgent need for different alternative treatment strategies in R/R adult ALL $[4,5]$.

Altogether, four types of immunotherapies have been developed to date, including naked monoclonal antibodies (mAbs) (such as rituximab, epratuzumab, and alemtuzumab), conjugated monoclonal antibodies (such as inotuzumab ozogamicin, SAR3419, and SGN-CD19A), bispecific $\mathrm{T}$ cell engager (BiTE) (such as blinatumomab), and chimeric antigen receptor (CAR) T cell therapy (Fig. 1). Naked monoclonal antibodies exert their cytotoxic effects through mechanisms such as antibodydependent cytotoxicity, complement-dependent cytotoxicity, and direct induction of apoptosis; moreover, direct blocking of leukemic cell receptors can lead to cell death if the signalings through the receptors are crucial for leukemic cell to survive. If a surface marker is known to internalize upon binding (such as CD19 and CD22), potent cytotoxins can be conjugated to the monoclonal antibody, resulting in an additional cytotoxic mechanism. BiTE conjugates two monoclonal antibodies recognizing leukemic cell and cytotoxic $\mathrm{T}$ cells (CTLs) and exerts its effects by specifically bridging CTLs and leukemic cells. CAR $\mathrm{T}$ cells utilizes 


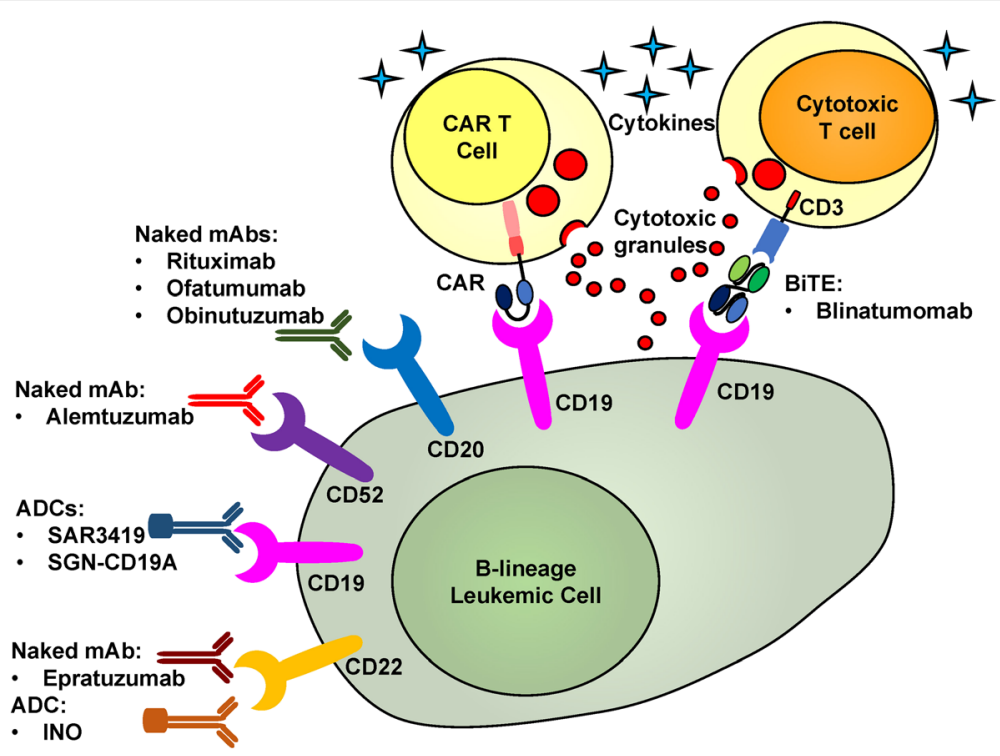

Fig. 1 Different mechanisms of immunotherapies treating ALL

engineered $\mathrm{T}$ cells by introducing leukemic celltargeting single-chain variant fragment $(\mathrm{scFv})$ chimerized with intracellular $\mathrm{T}$ cell activation domains. Both BiTE and CAR T cells lead to leukemic cell killing in mechanisms similar to cancer-specific CTLs, including releasing of cytotoxic granules, activation of deathrelated receptors, and releasing of cytokines. Compared with CAR T cell therapy, naked/conjugated mAbs and BiTE are more readily available and easier to manufacture; however, CAR T cell therapy as a "living drug" is more durable and repeat infusions are usually not needed. Based on clinical data, BiTE and CAR T cell therapy are more potent and generate better outcomes than naked/conjugated mAbs; however, these two modalities are associated with more severe side effects, such as cytokine release syndrome (CRS), and adverse neurologic events. In this review, we will discuss clinical and pre-clinical results of these different modalities in treating B ALL, focusing on the efficacy (Table 1) and the side effects (Table 2).

\section{CD20-targeting agents_rituximab, ofatumumab, and GA101}

CD20 is a surface marker of B-lineage lymphocytes with robust expression after the mid-stage of development. It is presented in $25 \%$ of pre-B ALL and nearly all mature ALL. The GRAALL (a Group for Research in Adult Acute Lymphoblastic Leukemia) study demonstrated a higher relapse rate (39 vs $20 \%, P=0.04$ ) and a worse event-free survival (EFS) exclusively in pre-B ALL patients with positive CD20 expression and a high white blood count, indicating worse outcomes are associated with positive CD20 expression [6].

\section{Rituximab}

Rituximab is a humanized murine mAb targeting CD20. Before its introduction to ALL treatment, rituximab has shown prolonged survival for patients with CD20+ nonHodgkin's lymphoma and Burkitt's lymphoma/leukemia [7]. Emerging results have confirmed its efficacy in ALL patients.

MD Anderson Cancer Center recruited patients with Ph-negative B ALL and treated with the modified hyperCVAD (cyclophosphamide, vincristine, doxorubicin and dexamethasone) regimens with or without rituximab. For the younger (age $<60$ years) subgroup, complete remission duration (CRD) and OS were better with the combination of hyper-CVAD and rituximab than with hyper-CVAD alone (69 vs $38 \% ; P<.001$ and 71 vs $47 \%$, $P=.003)$. However, no benefit from the addition of rituximab was noted in elderly patients (age $\geq 60$ years), in part because of deaths in CR from infections. The results suggest a role for rituximab use in patients with CD20+ ALL under 60 years old [8]. Similar outcomes were observed in a multicenter randomized trial comparing the pediatric-inspired GRAALL protocol to the same regimen plus rituximab $[9,10]$. Two hundred twenty patients aged 18-59 years old with newly diagnosed CD20positive Ph-negative B cell precursor (BCP)-ALL were enrolled from 2005 to 2014 . Rituximab $\left(375 \mathrm{mg} / \mathrm{m}^{2}\right)$ was given from induction to the first year of maintenance for a total of 16 to 18 infusions. After induction \pm salvage reinduction, the CR rate was 92 and $91 \%$ in rituximab and control arm, respectively. Patients treated in the rituximab arm had a lower cumulative incidence of relapse (CIR) (2-year CIR, 18 vs $30.5 \%$ in the control arm; $p=0.02$ ) and longer EFS (2-year EFS, 65 vs $52 \%$ 
Table 1 Major clinical trials on monoclonal antibodies treating acute lymphoblastic leukemia

\begin{tabular}{lllll}
\hline Targets & Medications & Patients & Regimens & Outcome \\
\hline CD20 & Rituximab & 216 pts with de novo Ph-negative & Combination of hyper-CVAD plus \\
& B ALL; median age was 46 years & rituximab & CRD and OS were better with the \\
& (range, 16-84) & & combination of hyper-CVAD plus rituximab III [8] \\
& & & $\begin{array}{l}\text { than with hyper-CVAD alone (69 vs 38\%; } \\
P<.001 \text { and 71 vs 47\%, } P=.003) \text { for the } \\
\text { younger pts (age }<60 \text { years) }\end{array}$
\end{tabular}

220 pts aged $18-59$ years old with newly diagnosed CD20-positive Ph-negative B cell precursor (BCP) ALL
Rituximab $\left(375 \mathrm{mg} / \mathrm{m}^{2}\right)$ was added to pediatric-inspired GRAALL protocol from induction to the first year of maintenance for a total of 16 to 18 infusions
Ofatumumab 55 pts with de novo ALL and 4 pts in CR previously treated: median age was 41 years (18-71) Ofatumumab given on courses 1

Hyper-CVAD in combination with ofatumumab and 3 , and 4 courses of MTX-Ara-C

CD19 Blinatumomab 116 pts with Ph-negative BCP ALL with hematologic $C R$ and MRD $\geq 10^{-3}$ after $\geq 3$ intensive chemotherapy treatments; Median age was 45 years (18-76) 36 pts with R/R pre-B ALL; median age was 32 years (18-77)

4-week continuous IV infusion, followed by a 2-week break (1 cycle). MRD responders in cycle 1 received up to 3 additional cycles or underwent HSCT

4-week continuous infusion followed by a 2-week interval

$360 \mathrm{mg} / \mathrm{m}^{2} /$ day on days $1,8,15$, and The ORR was $50 \%$ including 9 CR (30\%),

30 pts with $\mathrm{R} / \mathrm{R} C \mathrm{CD} 2+\mathrm{B}$ ALL median age was 35 years $(21-59)$
31 pts with R/R Ph-negative B ALL. Median age was 41 years $(21-69)$

Inotuzumab ozogamicin
90 pts with R/R pre-B ALL; median age was 39.5 years (range 4-84)
326 CD22-positive, R/R ALL pts underwent randomization, the first 218 (109 in each group) were included in the analysis of complete remission

57 pts with R/R CD22+ B ALL received mini-hyper-CVD regimen
Clofarabine $40 \mathrm{mg} / \mathrm{m}^{2} /$ day on days 2-6, cytarabine $1 \mathrm{~g} / \mathrm{m}^{2} /$ day on days $1-5$, epratuzumab $360 \mathrm{mg} / \mathrm{m}^{2} /$ day on days $7,14,21$, and 28

INO single-dose at $1.8 \mathrm{mg} / \mathrm{m}^{2}$ every 3-4 weeks, $n=49$; INO weekly at $0.8 \mathrm{mg} / \mathrm{m}^{2}$ on day 1 and at 0.5 $\mathrm{mg} / \mathrm{m}^{2}$ on days 8 and 15 , every 3 to 4 weeks, $n=41$

INO group: INO $\left(0.8-0.5 \mathrm{mg} / \mathrm{m}^{2}\right.$, weekly, 3 times per cycle; cycle length, 21-28 days; total number of cycles, 6); standard intensive chemotherapy: FLAG for up to 4 cycles, cytarabine plus mitoxantrone for up to 4 cycles, or high-dose cytarabine for up to 1 cycle

Mini-hyper-CVD regimen plus INO administered on day 3 of each of the first 4 cycles, rituximab (in pts whose cells were CD20-positive) and intrathecal chemotherapy were given for the first 4 courses
After induction \pm salvage reinduction, CR rate was 92 and $91 \%$ in the rituximab and control arm. Pts treated in the rituximab arm had a lower CIR (2-year CIR, 18 vs $30.5 \%$ in the control arm; $p=0.02)$ and longer EFS (2-year EFS, 65 vs $52 \%$ in the control arm; $p=0.038$ ), but not longer OS (2-year OS, 71 vs 64\% in the control arm; $p=0.095$ )

Phase III [9]

98\% CR rate after cycle 1, 53 (93\%) pts achieved MRD negativity.

The 3-year CRD and OS rates were 78 and $68 \%$, respectively

Complete MRD response after the first cycle was $78 \%$; complete MRD response rate was $80 \%$. Median OS and RFS were 18.9 and 36.5 months, respectively

$69 \%$ hematologic response and $88 \%$ of the responders also obtaining a molecular response (MRD level below $10^{-4}$ by PCR) within the first 2 cycles

1 CRi (3\%), and 5 PR (17\%). All pts have died (during aplasia $n=3$, progression $n=23$, multiple organ failure $n=1$ ), except the 3 responders still in CR, but yet recently enrolled

10 pts achieved CR and 6 achieved CRi for a CR/CRi rate of $52 \%$. The median OS was 5 months

17 pts (19\%) CR, 27 (30\%) CRp, and 8 (9\%) marrow CR (no recovery of counts). ORR marrow CR (no recovery of co similar single dose and weekly dose (57 vs $59 \%$ ). The median survival was 6.2 months: 5.0 months with single dose and 7.3 months with weekly dose

$C R$ rate was higher with INO than with standard therapy (80.7 vs. $29.4 \% p<0.001$ ) and a higher percentage of pts in the INO group achieved $<0.01 \%$ MRD (78.4 vs. $28.1 \%, P<0.001)$. Both PFS and OS were longer with INO (median PFS, 5.0 vs.

1.8 months, $P<0.001$; median OS, 7.7 vs. 6.7 months, $P=0.04$ )

The ORR was 71\%: 31 (53\%) CR, 13 (23\%) CRp, and 1 (2\%) CRi.

27 (47\%) pts proceeded to receive allo-HSCT. Pts who were treated with mini-hyper-CVD plus INO had a higher PFS rate and improved OS compared to a historical cohort with single-agent INO in R/R ALL (2-year PFS; 52 vs 36\%; $p=0.20$ : 2 -year OS; 44 vs. $25 \%$; $p=0.01$ )
Phase

|| [13]

Phase II [26]

Phase II [27]

Phase || [37]

Phase

II [38]

Phase II [40] 
Table 1 Major clinical trials on monoclonal antibodies treating acute lymphoblastic leukemia (Continued)

46 pts $\geq 60$ years with newly
diagnosed B cell ALL. Median
age is 68 years ( $60-81$ )

age is 68 years $(60-81)$

\section{Mini-hyper-CVD regimen plus INO given on day 3 of each of the first 4 cycles. Rituximab (in pts whose cells were CD20-positive) and intrathecal chemotherapy were given for the first 4 courses}

\begin{abstract}
Of the 42 pts evaluable for response, 40 Phase (95\%) achieved CR/CRp (35 CR, 5 CRp). Of II [43] the 44 pts assessed for MRD, 41 (93\%) achieved negative MRD (71\% of them at $(\mathrm{R})$. The mini-hyper-CVD + $\operatorname{lnO}+/-$ rituximab $(n=46)$ results appear superior to the historical data with HCVAD +/rituximab $(n=46)$ (3-year OS of 52 and $36 \%$, respectively, $p=0.05$ ).

Of 11 pts assessed for MRD, 8 had a 1-log reduction. After 51 months of follow-up, median OS was 55 months and DFS was 53 months progressed within a few months and all but one died
\end{abstract}

CD52 Alemtuzumab 24 pts with de novo ALL in CR1. A target dose of $30 \mathrm{mg}$ administered Median age was 37 years (18-77) 3 times per week for 4 weeks (12 doses) during post-remission therapy

12 pts with relapsed $(n=11)$ or refractory $(n=1) \mathrm{ALL}$, including four relapses post-HSCT

Alemtuzumab combined with granulocyte-colony stimulating factor (G-CSF)

Pts patients, CIR cumulative incidence of relapse, OS overall survival, CRD complete remission duration, $C R$ complete remission, $M R D$ minimal residual disease, $R F S$ relapse-free survival, $D F S$ disease-free survival, $R / R$ refractory/relapsed, $C R p$ complete remission in the absence of total platelet recovery, $C R i$ complete remission with incomplete hematologic recovery, $O R R$ overall response rate

in the control arm; $p=0.038)$, but not longer OS (2year OS, 71 vs $64 \%$ in the control arm; $p=0.095)$. When censoring patients who received allogeneic HSCT in first CR at transplant time, EFS and OS were longer in the rituximab arm (2-year EFS, 66 vs $53 \%$, and 2-year OS, 74 vs $63 \% ; p=0.021$ and 0.018 , respectively). These data indicated adding rituximab to the ALL chemotherapy protocol could improve the outcome for patients with CD20-positive, Ph-negative ALL, especially in younger adults.

Rituximab is among the most studied immunotherapies, and its safety has been well addressed. Due to its low toxicity, rituximab may be particularly useful in elder patients and patients who are unfit for more aggressive treatment [11]. However, several limitations were discovered: its efficacy is limited when administered alone; moreover, CNS relapse is common when rituximab is used as monotherapy because mAbs cannot cross the blood-brain barrier.

\section{Ofatumumab}

Ofatumumab (HuMax-CD20) is a second-generation anti-CD20 mAb that binds to a site different from rituximab. Ofatumumab targets a membrane proximal small-loop epitope on the CD20 molecule and is more potent than rituximab in inducing antibody-dependent cell-mediated cytotoxicity (ADCC) and complementdependent cytotoxicity (CDC) [12]. As a single agent, ofatumumab's adverse effects are mild, consisting primarily of grade 1 or 2 infusion reactions or infections. Only $9 \%$ of patients have grade 3 or 4 infections. In a phase II study of hyper-CVAD/MTX-Ara-C in combination with ofatumumab for adults with CD20-positive ALL, promising results have been achieved. Altogether, 55 patients with de novo ALL and 4 patients in CR with previous treatment received a median of 8 cycles (range, 1-8) of ofatumumab therapy. All but one patient (98\%) achieved a CR after cycle 1 , and 53 patients (93\%) achieved minimal residual disease (MRD) negativity. The 3 -year CRD and OS rates were 78 and 68\%, respectively. The 3-year OS in patients with CD20 $<20$ and $\geq 20 \%$ were 82 and $64 \%$, respectively $(p=0.96)$. This study proved safety and high effectiveness in patients with CD20-positive ALL $[13,14]$. As ofatumumab binds to a different epitope than rituximab, the medication may

Table 2 Common side effects of different immunotherapies

\begin{tabular}{lll}
\hline Targets & Medications & Side effects \\
\hline CD20 & Rituximab & $\begin{array}{l}\text { Most common side effect is mild to moderate infusion reactions. Rare cases of severe mucocutaneous reactions, } \\
\text { HBV reactivation, and progressive multifocal leukoencephalopathy }\end{array}$ \\
& Ofatumumab & Primarily grade 1 or 2 infusion reactions or infections \\
CD19 & SAR3419 & Dose-limiting reversible severe vision changes associated with corneal changes \\
& Blinatumomab & Superficial microcystic keratopathy \\
& Epratuzumab & Seizure, liver toxicity \\
CD22 & INO & Liver toxicity, veno-occlusive disease in transplant patients \\
& Alemtuzumab & Severe neutropenia, CMV viremia \\
\hline
\end{tabular}


also be used to overcome rituximab-resistant disease. Nonetheless, longer follow-up and randomized studies are warranted in the future.

\section{Obinutuzumab (GA101)}

Obinutuzumab, a type II glycoengineered humanized anti-CD20 mAb, has shown potent activity in CLL and has been FDA-approved for the upfront treatment of CLL. The post-translational glycoengineering modification of obinutuzumab can enhance its binding affinity to the FccRIII receptors on immune effector cells that would promote ADCC, while at the same time decrease CDC. Obinutuzumab is potentially more potent than other anti-CD20 mAbs due to its ability to directly induce cell death [15].

Encouraging preclinical results have been reported in ALL cell lines and xenografts [12]. However, no clinical studies in ALL patients have been performed yet. Thus, future studies are awaited as it may offer another option for the treatment of ALL.

\section{CD19-targeting agents-SAR3419, SGN19a, and blinatumomab}

CD19 is present in $90 \%$ of pre-B and mature ALL leukemic cells. Its high expression rate makes it an ideal target for immunotherapy. However, the antigen is known to internalize upon binding to antibody, making it an unsuitable target for naked mAbs. Nonetheless, the internalization property makes it an attractive target for immunoconjugate therapy.

\section{SAR3419}

SAR3419 is an antibody-drug conjugate (ADC) with a humanized anti-CD19 antibody conjugated to maytansin, a potent antimitotic agent. After binding to CD19positive lymphoblast, SAR3419 is internalized and processed to release the active maytansin metabolites that induce both cell cycle arrest and apoptosis [16].

In phase I studies conducted in patients with nonHodgkin's lymphoma, the major dose-limiting toxicity is reversible severe blurred vision, which was associated with epithelial corneal changes. Given the adverse effect, the maximally tolerated dose was $160 \mathrm{mg} / \mathrm{m}^{2}$ intravenously every 3 weeks [17]. In studies using CD19-positive pre-B cell ALL and mixed lineage leukemia (MLL) xenografts, the administration of SAR3419 delayed disease progression, even in chemotherapy-resistant xenograft models [18]. Unfortunately, a phase II multicenter, single-arm clinical trial (NCT01440179) was prematurely terminated due to modest activity of SAR3419 compared with its competitors. In this study, patients received SAR3419 induction monotherapy (55, 70, and $90 \mathrm{mg} /$ $\mathrm{m}^{2}, \leq 8$ weekly dosed); the responding patients were eligible for maintenance therapy (biweekly for $\leq 24$ weeks).
Of the 17 evaluable patients, only 4 had a disease response (estimated overall response rate (ORR), 25.5\%; $80 \% \mathrm{CI}, 14.2-39.6 \%$ ). The duration of response (DOR) was only 1.9 months (range, 1-5.6 months) [19], indicating SAR3419 monotherapy is unpromising in the treatment of R/R ALL. Thus, the unfavorable efficacy and dose-limiting toxicity may hinder further development of SAR3419.

\section{SGN-CD19A}

SGN-CD19A (denintuzumab) is a novel ADC composed of a humanized anti-CD19 mAb linked to a microtubuledisrupting agent monomethyla-uristatin F (MMAF). The ADC binds to CD19, internalizes, and releases MMAF, which ultimately results in G2-M phase growth arrest and induction of apoptosis. In a phase I doseescalation study (NCT 01786096), 49 patients with R/R ALL $(n=40)$ or lymphoma $(n=9)$ were treated with weekly IV SGN-CD19A (0.3-4.5 $\mathrm{mg} / \mathrm{kg})$ or every 3 weeks $(0.5-6 \mathrm{mg} / \mathrm{kg})$. Among the 33 evaluable patients, objective responses were observed in 30\% (10 of 33), including 6 of 25 patients on the weekly schedule and 4 of 8 patients on the every 3 -week schedule. SGNCD19A was generally well tolerated with superficial microcystic keratopathy being the most common toxicity, which might require routine steroid eye drop prophylaxis [20]. After all, promising results in heavily pretreated $R / R$ patients and safety profile suggest opportunities for combination with other conventional anti-leukemic therapies in lymphoblastic malignancies.

\section{Blinatumomab}

Blinatumomab is the first-in-class BiTE construct, which binds to both CD3 on CTLs and CD19 on B cells. The construct can facilitate CTL activation and expansion, which will result in effective lysis of CD19-positive cells, through release of cytokines and the pore-forming perforin system [21, 22]. (Fig. 1).

Pharmacokinetic analyses from a phase II study in ALL patients found rapid and sustained depletion of B cells, with the level becoming undetectable at a mean of 2.18 days (range, 0.03 to 13.94 days) [23, 24]. On the other hand, circulating $\mathrm{T}$ cells were initially depleted from the peripheral blood within hours of blinatumomab infusion but recovered to baseline or higher within a few days, followed by a polyclonal expansion of $\mathrm{T}$ cells expressing the activation marker CD69 [23]. Accordingly, many patients experienced a CRS 1-2 days after the infusion, which was mediated by transient release of inflammatory cytokines interleukin (IL)-2, IL-6, IL10 , tumor necrosis factor and interferon $-\gamma$ from blinatumomab-engaged $\mathrm{T}$ cell effectors. Cytokine levels declined after day 2 , and these spikes generally did not recur with future cycles [25]. 
In a phase II study of 21 patients with persistent MRD, the single-agent blinatumomab was continuously infused at $15 \mu \mathrm{g} / \mathrm{m}^{2} /$ day for a 4 -week period followed by a 2week treatment-free interval before starting the next cycle. The study achieved a molecular response rate of $80 \%$ and long-term relapse-free survival (RFS) of $61 \%$, after a median follow-up of 33 months [24]. In the BLAST study, 88 of the 106 ALL patients (76\%) achieved MRD after the first cycle of blinatumomab, including high-risk subgroups such as patients in second-line treatment, patients with high MRD burden, and older patients. With median follow-up of 29.5 months, median OS and RFS were 18.9 and 36.5 months, respectively. MRD complete response achieved in the first cycle was associated with longer OS (median OS 40.4 vs 12.0 months, $P=.001)$ and RFS (35.2 vs 7.1 months, $P=0.002)$, compared with not achieving an MRD complete response after the first cycle [26].

Based on the positive experience in adult patients with MRD-positive B cell lineage ALL, a phase II study of blinatumomab enrolled 36 Ph-negative pre-B ALL adults with primary refractory disease or relapsed after chemotherapy or HSCT. It led to $69 \%$ CR or CR with incomplete count recovery (CRi), and $88 \%$ of the responders also obtaining a molecular response (MRD level below $10^{-4}$ by PCR) within the first two cycles of drug administration. The median OS was 9.8 months (95\% CI, 8.5 to 14.9 months), and the median RFS was 7.6 months (95\% CI, 4.5 to 9.5 months) [27]. Another study of 189 patients with high-burden R/R B ALL showed a CR/CRi rate of $43 \%$ and a median OS rate of 6.1 months [28]. Safety profile appears favorable in these studies, with CRS and neurologic events being the most severe toxicities.

Despite the promising initial results, some patients do not respond to blinatumomab or experience disease progression after an initial response. The causes of primary resistance remain unknown. However, several mechanisms have been proposed. One possible mechanism is the selection of CD19-negative subclones, as leukemic cells can still maintain proliferation without CD19 expression [29]. Further, increased regulatory $\mathrm{T}$ (Treg) cells in combination with high lactic dehydrogenase level predicted resistance to blinatumomab [30]. Activated Tregs secrete IL-10 suppressing T cell proliferation, leading to treatment failure. Upregulation of programmed death-ligand 1 (PD-1) on leukemia cells after blinatumomab treatment is also a potential immune escape mechanism $[31,32]$. Further studies are warranted to analyze the significance of the PD-1/PD-L1 interplay as a resistance mechanism to blinatumomab.

Besides blinatumomab, other BiTEs are also under active developing. Recently, a disulfide-stabilized form of BiTE was tested which showed increased efficient [33].

\section{CD22-targeting agents-epratuzumab and inotuzumab ozogamicin}

CD22 is expressed on leukemic blasts in 90\% of preB ALL and mature ALL. Like CD19, CD22 is rapidly internalized upon antibody binding. Possible mechanisms of action of anti-CD22 antibodies include ADC, modulation of $\mathrm{B}$ cell signaling, and inhibition of proliferation [34].

\section{Epratuzumab}

Epratuzumab is a naked, humanized anti-CD22 immunoglobulin G1 (IgG1) that is internalized after binding to CD22. Engagement of CD22 with epratuzumab leads to direct phosphorylation of key upstream inhibitory receptors of BCR signaling [35]. Epratuzumab has been used as a single agent (4 doses of intravenous epratuzumab $360 \mathrm{mg} / \mathrm{m}^{2}$ twice a week) followed by standard Children's Oncology Group (COG) reinduction chemotherapy regimen in 15 pediatric patients with relapsed pre-B ALL. Although this strategy did not improve CR in comparison with historical controls (65 vs. 66\%), more patients achieved negative MRD status (42 vs. 25\%, $p=0.001$ ). The more favorable rate of MRD negativity after addition of epratuzumab suggests that this antibody may enhance the response to cytotoxic chemotherapy [36]. However, further follow-up is needed to determine whether the deeper remission level translates into improved DFS or OS. In adult ALL, the Southwest Oncology Group (SWOG) evaluated epratuzumab combined with clofarabine plus cytarabine in 31 patients experiencing first or later relapsed disease. Overall, the response rate was $52 \%$, significantly higher than that of SWOG's previous trial with clofarabine/cytarabine alone (17\%) [37]. These data provided the groundwork for a randomized phase III trial in children with relapsed ALL evaluating chemotherapy with or without epratuzumab (NCT01802814). Recently, in a phase II prospective study, epratuzumab was combined with hyper-CVAD in younger patients (18-59 years old) with $R / R$ CD22+ B ALL. Among the 30 patients ultimately considered for analyses, the ORR was only $50 \%$, with $45 \%$ of CR/CRi patients achieved negative MRD. All patients in CR/CRi and 1 patient in PR received a consolidation chemotherapy. However, at the time of analysis, all patients died except for the recently enrolled responders still in $\mathrm{CR}$ [38]. The short-lived improvement and overall disappointing outcome could be explained by an insufficient disease load decrease and/or by escape of the blast cells to epratuzumab. The results suggested that epratuzumab should be tested within first-line chemotherapies as it may participate to decrease the MRD level. Because CD22 is internalized upon binding, we expect conjugating cytotoxic agents with epratuzumab would result in more favorable outcomes. 


\section{Inotuzumab ozogamicin (INO)}

Inotuzumab ozogamicin (INO) is an ADC that consists of calicheamicin (a potent DNA-binding cytotoxic agent) attached to an engineered humanized monoclonal immunoglobulin G4 (IgG4) antibody targeting CD22. INO binds CD22 with sub-nanomolar affinity and is rapidly internalized, delivering the conjugated calicheamicin intracellularly. Calicheamicin binds to the minor DNA grove, causing double-strand DNA cleavage and cell apoptosis.

In a single-institution phase II study, 49 patients with $\mathrm{R} / \mathrm{R}$ ALL were treated with $1.8 \mathrm{mg} / \mathrm{m}^{2}$ INO every 34 weeks as a single agent. It resulted in an ORR of $57 \%$ (18\% CR and 39\% CRi) and median OS of 5.1 and 7.9 months in all patients and 28 responders, respectively. A total of 27 patients who achieved complete morphological response were assessed for MRD, and 63\% (17 of 27) of patients was found to have MRD-negative status. Abnormal liver function tests were the most significant adverse events observed and were graded as severe in $31 \%$ of patients [39]. To optimize the benefit-risk ratio of INO, a weekly dosing regimen was evaluated in 41 patients based on preclinical studies [40]. Weekly drug administration at a lower dose $\left(0.8 \mathrm{mg} / \mathrm{m}^{2}\right.$ on day $1,0.5 \mathrm{mg} / \mathrm{m}^{2}$ on days 8 and 15) was associated with similar efficacy (59\% ORR). However, liver toxicity was seen in only 11 of $41(27 \%)$ patients with weekly INO compared with 28 of 49 (57\%) with single-dose INO. This study indicates that more frequent but lower dose of INO may reduce toxicities while maintain the efficacy. Recently, a global, open-label, randomized phase III study confirmed the notion. Patients were randomly assigned to receive either INO $\left(0.8-0.5 \mathrm{mg} / \mathrm{m}^{2}\right.$, weekly, three times per cycle, cycle length of 21-28 days, 6 total cycles) or standard intensive chemotherapy. The CR rate was higher with INO than with standard chemotherapy (80.7 vs. $29.4 \% p<0.001$ ). Moreover, a higher percentage of patients in the INO group achieved MRD-negative status $(78.4$ vs. $28.1 \%, P<0.001)$. Both PFS and OS were longer with INO (median PFS, 5.0 vs. 1.8 months, $P<0.001$; median OS, 7.7 vs. 6.7 months, $P=0.04$ ) [41]. Because HSCT is considered to be the only curative treatment option, the capacity of INO to increase the number of patients who can proceed to HSCT is encouraging.

The promising results of INO as a single agent led to the initiation of a clinical trial combining INO with non-myelosuppressive chemotherapy. A total of $57 \mathrm{pa}$ tients with R/R CD22+ B ALL received INO, in combination with mini-hyper-CVD regimen, rituximab, and intrathecal chemotherapy. The ORR was $71 \%$, with $47 \%$ patients proceeding to allo-HSCT. Compared with historical cohort, patients treated with mini-hyperCVD plus INO had a higher PFS rates and improved OS (2-year PFS; 52 vs. $36 \%$; $p=0.20$ : 2-year OS; 44 vs.
$25 \% ; p=0.01)$ [42]. These encouraging results provided an option of combining INO with low-intensity chemotherapy in patients with R/R ALL.

The same regimen of mini-hyper-CVD combined with INO was also evaluated in elderly patients $\geq 60$ years with newly diagnosed B ALL [42]. Of the 42 patients evaluable for response, 40 (95\%) achieved CR/CRp. Of the 44 patients assessed for MRD, 41 (93\%) achieved negative MRD. The results appear superior to historical data with hyper-CVAD alone in a similar patients' population (3-year overall survival (OS) rates of 52 and $36 \%$, respectively, $p=0.05$ ) [43].

\section{CD52-targeting agent-alemtuzumab}

CD52, an antigen involved in $\mathrm{T}$ cell activation, is expressed in $70 \%$ of T ALL and pre-B ALL. Alemtuzumab is a fully humanized monoclonal antibody against CD52. Alemtuzumab has been evaluated in the CALGB phase I trial of 24 patients with de novo CD52+ ALL after the successful achievement of CR with induction chemotherapy [44]. The drug was given three times weekly for a target dose of $30 \mathrm{mg}$ subcutaneously. After 51 months of follow-up, median OS was 55 months and DFS was 53 months. Notably, alemtuzumab was associated with increased risk of neutropenia and CMV viremia, supporting a role for stimulating factor support. Recently, a phase II study assessed the efficacy of alemtuzumab combined with granulocyte colonystimulating factor (G-CSF) in 12 patients with $R / R$ ALL. G-CSF was administered during alemtuzumab administration. Although 4 of the 12 patients achieved $\mathrm{CR}$, all patients progressed within a few months and all but 1 died [45]. The current studies only demonstrate modest activity of alemtuzumab against T ALL or B ALL, yet significant adverse effects have been reported extensively. These results would potentially limit further development of alemtuzumab.

\section{Chimeric antigen receptor T cell therapy}

Chimeric antigen receptors (CARs) consist of an extracellular binding domain ( $\mathrm{scFv}$ ), hinge domain, transmembrane domain, and intracellular signaling domains. When expressed in autologous $\mathrm{T}$ cells (or donor $\mathrm{T}$ cells in the post-transplant setting), CARs redirect the CTLs toward antigen-expressing tumor cells in an HLA-independent manner. DNA constructs encoding such CARs could be stably incorporated into human T cells via lentiviral or $\gamma$-retroviral transductions, electroporation, or "Sleeping Beauty" transposon.

The engineering of CAR T cells evolves over time. The first-generation CAR $\mathrm{T}$ cells are only incorporated with $\mathrm{T}$ cell receptor $\mathrm{CD} 3 \zeta$ signaling domain. This construct revealed weak proliferation ability, poor anti-tumor effect, and short survival of T cells [46, 47]. Second- and 
third-generation CAR $\mathrm{T}$ cells are incorporated with costimulatory domains, such as CD137 (4-1BB), CD28, CD27, or CD134 (OX40), which significantly enhanced the expansion, persistence, and potency of CAR T cells. Among them, CD28 and 4-1BB are currently the most widely used costimulatory domains. Studies showed that CD28 endued CAR T cells with stronger killing ability, while 4-1BB granted longer persistence in vivo.

Expansion of CAR $\mathrm{T}$ cells is essential. The CAR T cells are first expanded ex vivo to a goal cell count around $3 \times 10^{6}$ cells $/ \mathrm{kg}[48,49]$. Following infusion, circulating CAR T cells expand in vivo by 1000 folds within 7-14 days. CAR T cells have the potential to enter cerebrospinal fluid, exerting anti-leukemic activity in this sanctuary site, and persist after infusion [50]. However, the persistence of CAR T cells within patients varied across the studies. Stephan et al. report persistence of CD19-CAR T cells for 3-39 months after infusion in patients with ongoing responses, whereas Davila et al. found the levels undetectable by 3 months $[51,52]$.

\section{Clinical outcome of CD19-targeted CAR $T$ cells in R/R ALL}

CAR $\mathrm{T}$ cell therapy has achieved promising results in multiple clinical trials (Table 3). The majority of the trials are led by three research institutes-the University of Pennsylvania (UPenn), the National Cancer Institute (NCI), and the Memorial Sloan Kettering Cancer Center (MSKCC).

Table 3 Major clinical trials on anti-CD19 CAR T cell therapy

\begin{tabular}{|c|c|c|c|c|c|}
\hline $\begin{array}{l}\text { Institution } \\
\text { and trial no. }\end{array}$ & $\begin{array}{l}\text { Costimulatory } \\
\text { domain and } \\
\text { gene transfer }\end{array}$ & Patient & $\begin{array}{l}\text { Lymphodepleting } \\
\text { chemotherapy }\end{array}$ & Cell dose & Outcomes \\
\hline $\begin{array}{l}\text { MSKCC } \\
\text { NCT01044069 [53] }\end{array}$ & $\begin{array}{l}\text { CD28, } \\
\text { y-retrovirus }\end{array}$ & $\begin{array}{l}\text { Adults with R/R ALL } \\
\text { including } \mathrm{Ph}+\mathrm{ALL} \text {, } \\
n=44\end{array}$ & Cy or flu/cy & $1-3 \times 10^{6}$ cells $/ \mathrm{kg}$ & $\begin{array}{l}\text { CR: } 36 / 43 \text { (84\%) with } 29 / 35 \text { (83\%) of } \\
\text { responders negative for MRD; OS: } 76 \% \\
\text { (MRD-CR cohort) and } 14 \% \text { (MRD + CR } \\
\text { cohort) at } 6 \text { months }\end{array}$ \\
\hline $\begin{array}{l}\mathrm{NCl} \\
\mathrm{NCT} 01593696[54]\end{array}$ & $\begin{array}{l}\text { CD28, } \\
\text { y-retrovirus }\end{array}$ & $\begin{array}{l}\text { Children and young } \\
\text { adults with R/R ALL, } \\
n=51\end{array}$ & $\begin{array}{l}\text { Cy, low-dose flu/cy, } \\
\text { FLAG, ifosfamide/ } \\
\text { etoposide or } \\
\text { high-dose flu/cy }\end{array}$ & $\begin{array}{l}0.03 \times 10^{6}-3 \times \\
10^{6} \text { cells } / \mathrm{kg}\end{array}$ & $\begin{array}{l}\text { CR: } 31 / 51 \text { (60.8\%) with } 28 / 31 \text { ( } 90 \% \text { ) } \\
\text { of responders negative for MRD } \\
\text { OS: } 34.7 \% \text { (receiving flu/cy) at } 38 \text { months } \\
\text { LFS: } 49.5 \% \text { (MRD- CR) at } 18 \text { months } \\
\text { LFS: } 62 \% \text { (MRD- CR cohort having a } \\
\text { subsequent HSCT) at } 18 \text { months }\end{array}$ \\
\hline $\begin{array}{l}\text { Multicenter } \\
\text { studies } \\
\text { NCT02614066, } \\
\text { NCT02625480 [55] }\end{array}$ & $\begin{array}{l}\text { CD28, } \\
\text { y-retrovirus }\end{array}$ & $\begin{array}{l}\mathrm{R} / \mathrm{R} \text { ALL aged } \geq 18 \\
\text { years (ZUMA-3) or } 2-21 \\
\text { years (ZUMA-4) with } \geq 25 \% \\
\text { marrow blasts } \\
\text { Ph+ ALL and low-burden } \\
\text { central nervous system } \\
\text { disease are eligible }\end{array}$ & $\mathrm{Flu} / \mathrm{cy}$ & $\begin{array}{l}1 \text { or } 2 \times 10^{6} \\
\text { anti-CD19 } \\
\text { CAR T cells/kg }\end{array}$ & CR: $5 / 5$ (100\%) \\
\hline $\begin{array}{l}\text { FHCRC } \\
\text { NCT01865617 [72] }\end{array}$ & 4-1BB, Lentivirus & $\begin{array}{l}\text { Adult with } R / R A L L \\
n=30 \\
29 \text { evaluable }\end{array}$ & $\begin{array}{l}\text { Cy } \pm \text { etoposide } \\
\text { or cy/flu }\end{array}$ & $\begin{array}{l}2 \times 10^{5} \text { or } 2 \times 10^{6} \\
\text { or } 2 \times 10^{7} \text { cells/kg } \\
1: 1 \mathrm{CD} 4+: \text { CD } 8+\end{array}$ & CR: 27/29 (93\%) \\
\hline $\begin{array}{l}\text { UPenn/CHOP } \\
\text { NCT01626495 [56] }\end{array}$ & 4-1BB, Lentivirus & $\begin{array}{l}\text { Children and young adults } \\
\text { with R/R ALL, } n=53\end{array}$ & $\begin{array}{l}\text { Investigator's } \\
\text { choice }\end{array}$ & $\begin{array}{l}1-17.4 \times 10^{6} \\
\text { cells } / \mathrm{kg}\end{array}$ & $\begin{array}{l}\text { CR: } 50 / 53(94 \%) \text { with } 47 / 50(94 \%) \\
\text { of responders negative for MRD } \\
\text { OS: } 78 \% \text { at } 12 \text { months } \\
\text { RFS: } 72 \% \text { at } 6 \text { months }\end{array}$ \\
\hline $\begin{array}{l}\text { ELIANA } \\
\text { (global trial) } \\
\text { NCT02435849 [57] }\end{array}$ & 4-1BB, Lentivirus & $\begin{array}{l}\text { Children and young adults } \\
\text { with R/R ALL, } 29 \text { pts } \\
\text { reaching D28 prior to the } \\
\text { data cutoff }\end{array}$ & $\mathrm{Flu} / \mathrm{cy}$ & $\begin{array}{l}0.2-4 \times 10^{6} \\
\text { cells } / \mathrm{kg}\end{array}$ & $\begin{array}{l}\text { CR: } 24 / 29(83 \%) \text { with all of responders } \\
\text { negative for MRD }\end{array}$ \\
\hline $\begin{array}{l}\text { ENSIGN } \\
\text { (US multicenter } \\
\text { trial) } \\
\text { NCT02228096 [58] }\end{array}$ & 4-1BB, Lentivirus & $\begin{array}{l}\text { Children and young adults } \\
\text { with R/R ALL, } n=29\end{array}$ & $\begin{array}{l}\text { Flu/cy, or none } \\
\text { due to leukopenia }\end{array}$ & $\begin{array}{l}2-5 \times 10^{6} \text { cells } / \mathrm{kg} \\
\text { for } \leq 50 \mathrm{~kg}, 1- \\
2.5 \times 10^{8} \text { cells } \\
\text { for }>50 \mathrm{~kg}\end{array}$ & $\begin{array}{l}\text { ORR (CR }+ \text { CRi): } 20 / 29(69.0 \%) \\
\text { with } 18 / 29(62.1 \%) \text { responders negative } \\
\text { for MRD } \\
\text { RFS: } 66.4 \% \text { at } 6 \text { months } \\
\text { OS: } 75.7 \% \text { at } 6 \text { months }\end{array}$ \\
\hline $\begin{array}{l}\text { UPenn/CHOP } \\
\text { NCT02374333 [74] }\end{array}$ & $\begin{array}{l}\text { 4-1BB, Lentivirus } \\
\text { humanized } \\
\text { anti-CD19 } \\
\text { sCFv domains }\end{array}$ & $\begin{array}{l}\text { Children and young adults } \\
\text { with R/R ALL, with or } \\
\text { without prior exposure to a } \\
\text { CAR T cell product, } n=30\end{array}$ & Flu/cy & No mention & $\begin{array}{l}\text { CR: } 26 / 30 \text { (87\%) } \\
\text { CR for patients previously treated } \\
\text { with CAR T: } 7 / 11(64 \%) \text { with } \\
5 / 7 \text { (71\%) of responders negative for MRD } \\
\text { CR for patients with no prior exposure } \\
\text { to CAR T: } 19 / 19(100 \%) \text { with } 19 / 19 \\
\text { (100\%) of responders negative for MRD }\end{array}$ \\
\hline
\end{tabular}


A recent study from MSKCC reported the efficacy of CAR T cell therapy in 44 adults with R/R B ALL. Of the 43 patients evaluable for response, 36 patients (84\%) achieved CR after 19-28z CAR T cell (JCAR015, Juno Therapeutics, Seattle, WA) infusion. Among them, 29 (83\%) achieved MRD negativity (MRD-CR). The median OS for all patients and MRD-CR patients was 8.5 and 10.8 months, respectively. Posttreatment MRD status emerged as a strong predictive marker of OS. The OS at 6 months was $76 \%$ (95\% CI 51-89) in the MRD-CR cohort vs. $14 \%$ (95\% CI 8-45) in the MRD+ CR cohort. However, this study did not show significant survival superiority in patients who underwent allo-HSCT after CAR $\mathrm{T}$ cell infusion than those who did not (OS at 6 months was 70\% in patients who underwent allo-HSCT vs. $64 \%$ in patients who did not receive allo-HSCT) [53]. In contrast, researchers from $\mathrm{NCI}$ showed that long-term outcomes were superior among patients with post-CAR $\mathrm{T}$ HSCT. In their study, $31(60.8 \%)$ of 51 R/R ALL patients achieved a CR with 28/31 (90\%) of responders negative for MRD. Relapse was significantly more common in patients who did not have a HSCT after CAR T therapy $(6 / 7 ; 85.7 \%)$ compared to those who did $(2 / 21 ; 9.5 \%)$ $(p=0.0001)$. Even when counting in the transplant-related mortality, the median leukemia-free survival (LFS) in the HSCT group was significantly longer $(\mathrm{HR}=16.9$, $p=0.0006$ ) [54]. Based on the aforementioned excellent outcomes, a multicenter, phase $1 / 2$ study called ZUMA-3 and ZUMA- 4 that enroll adult (aged $\geq 18$ years) and pediatric (aged 2-21 years) R/R ALL patients were started [55]. Researchers from the UPenn also reported their experience with CTL019 (Novartis, Basel, Switzerland) in patients with R/R ALL. In a recent study of largely pediatric patients, 94\% (50/53) achieved CR, with MRD negativity in 47 responding patients. RFS was $72 \%$ at 6 months (95\% CI, 59-87\%) and $44 \%$ at 12 months (95\% CI, 30-65\%), and OS was 78\% at 12 months (95\% CI, 6791\%) [56]. This single-center trial of CTL019 for R/R ALL showed prolonged CAR $\mathrm{T}$ cell persistence along with long-term CR without further therapy in the majority of patients. However, the high efficacy and a similar safety profile of CTL019 have yet to be reproduced in multicenter trials, such as the first US multicenter trial (ENSIGN) and the first global trial (ELIANA) $[57,58]$.

Although the above studies differed in CAR designs, $T$ cell manufacturing, conditioning regimens, patients' age, leukemia burdens, and $\mathrm{T}$ cell dosages, each trial was comparably effective in treating R/R ALL, reaching $90 \%$ even in heavily pretreated patients. As a result, these preliminary clinical trials have paved the way for more ongoing studies.

In addition to autologous CD19-CAR $\mathrm{T}$ cells, the potential of donor-derived CD19-CAR T cells to treat relapse after allo-HSCT was also intriguing [59]. Some preliminary results have been reported [60, 61]. Brudno et al. conducted a clinical trial using allogeneic donorderived CAR $\mathrm{T}$ cells in $\mathrm{B}$ cell malignancy patients who relapsed after allo-HSCT [62]. Eight of the 20 treated patients obtained remission. None of the patients developed new onset graft-versus-host disease (GVHD) after the infusion. The result was similar with a previous study from Baylor College of Medicine using donorderived CD19-redirected virus-specific T cells, in which no evidence of GVHD was reported [61]. However, in another study, Dai et al. reported for the first time of GVHD occurrence in 2 of the 3 patients that received donor-derived CAR T cells [63]. The GVHD might be related to a higher dose of infused CAR $\mathrm{T}$ as well as mixed chimerism in recipients. In addition, different CAR designs may also play a role. Using a mouse alloHSCT model, Smith et al. found that adoptive transfer of murine donor m1928z CAR T cells (CAR with CD28 costimulatory domain) caused significantly less GVHD compared to m19delta T cells (CAR with no costimulation) and $\mathrm{m} 19 \mathrm{BBz} \mathrm{T}$ cells (CAR with $4-1 \mathrm{BB}$ costimulatory domain) [64]. This result is in accordance with the clinical observations, as the 4-1BB domain was incorporated in the donor-derived CAR $\mathrm{T}$ cells that caused GVHD in Dai's case [63].

Even more interestingly, allogeneic CD19 CAR T cells could be applied to patients without prior HSCT. The infusion of allogeneic CAR T cells could potentially augment the killing effect through additional alloreactive-attacking capability. Cai et al. reported a case where the patient received co-infusion of haplo-identical allogeneic CAR T cells and mobilized peripheral blood stem cells (PBSCs) following induction therapy. The patients achieved MRDCR and full donor engraftment, with only mild toxicity [65]. Although the result seems intriguing, potential complications such as GVHD need further study.

\section{Toxicities of CD19-targeted CAR T cells}

Toxicities associated with CAR T cell therapy are reported in nearly all clinical trials. Most toxicities were mild and reversible, including fever, chills, hypotension, dyspnea, headaches, and fatigue. The three main concerning toxicities are on-tumor off-target toxicity, CRS, and neurotoxicity. On-tumor off-target toxicity is related to the inability of CAR $\mathrm{T}$ to distinguish between tumor and normal cells, since the CD19 antigen is homogeneously expressed by both normal and malignant $\mathrm{B}$ lymphocytes. The toxicity can lead to B cell aplasia, which might cause agammaglobulinemia. Low immunoglobulin level will increase the risk of opportunistic infections. But it is preventable with immunoglobulin infusions and/or administration of antibiotics. CRS is caused by significant production of inflammatory cytokines secreted by activated CAR T cells $[66,67]$. The onset of CRS is variable, ranging from 
$24 \mathrm{~h}$ to 3 weeks following CAR $\mathrm{T}$ infusion [51, 68]. While mild CRS is reported in almost all patients, severe CRS occurs in about $30 \%$ of patients. Patients with high leukemia burden are at increased risk of more severe CRS, presenting as vascular leak and hypotension leading to multi-organ system dysfunction. These severe complications will often need aggressive medical management, including hemodynamic support, mechanical ventilation, and application of tocilizumab (an IL-6 inhibitor) and, in life-threatening conditions, corticosteroids. It is worth noting, however, that administration of corticosteroids may also minimize or eliminate the CAR T cell activity. Neurological toxicities are also accompanied by CAR $\mathrm{T}$ infusion, including delirium, dysphasia, akinetic mutism, and seizures. In November 2016, two patients died from cerebral edema in a phase II ROCKET study testing the investigational anti-CD19 CAR T cell JCAR015 (Juno Therapeutics, Seattle, WA). Considering in the previous three deaths in July 2016, the trial was halted due to concern of safety [69]. Juno highlighted the lower levels of toxicity in both ALL and other B cell malignancies using their 4-1BB CAR $\mathrm{T}$ products with defined CD4:CD8 composition (JCAR017 and JCAR014). Thus, they speculated the flu/cy conditioning regimen or the CD28 costimulatory domain used in JCAR015 that may trigger more rapid expansion of $\mathrm{T}$ cells and disruption of the blood-brain barrier might be the culprits. However, other groups (such as Kite/NCI) using CD28 CARs appeared to have no significant neurotoxicity, even though they also used flu/cy for conditioning. Thus, the etiology remains unproven.

\section{Causes and management of relapse after CAR T therapy}

If CAR $\mathrm{T}$ could be durably detected in the recipients, the chances of relapse would decrease [70]. In one study, loss of functional persistence of CAR $\mathrm{T}$ was associated with CD19+ relapse with a hazard ratio (HR) of 34 $(p=0.013)$ [71]. Some studies sought to prolong CAR T persistence by reinfusion of CAR $\mathrm{T}$ in patients with evidence of poor persistence. However, investigators from Fred Hutchinson Cancer Research Center (FHCRC) detected a cytotoxic CD8+ T cell response to CAR in some patients who failed to achieve engraftment of CAR $T$ cells after second infusions; epitope mapping in 1 patient identified immunogenic epitopes within the murine FMC63 scFv [72]. Thus, repeated infusion would be ineffective in this subset of patients with rapid CAR cell loss mediated by immune rejection. In this condition, retreatment with CD19-directed CAR T expressing a humanized scFv may induce second remission of ALL [73]. UPenn has published the results of a phase I study of humanized CTL119 at the 2016 ASH meeting. Thirty children and young adults with R/R B ALL with or without prior exposure to CAR $T$ cells were enrolled. They found CTL119-induced remissions in 64\% (7/11) of patients previously treated with murine CD19-directed CAR T cells and $100 \%$ of CAR-naïve patients [74]. Inadequate lymphodepletion may be another reason for limited CAR T persistence. Indeed, addition of fludarabine to the lymphodepletion regimen was showed to enhance CAR $T$ persistence and prevent transgene rejection [75]. In addition, combining CAR $T$ therapy with other medications such as PD-1 inhibitor [76] or BTK inhibitor [77] was also showed to improve CAR T cell persistence. Loss of surface CD19 expression is another cause of relapse [69]. Interestingly, Lacey et al. reported a case where the relapsed CD19-negative leukemia was originated from a single leukemic cell accidentally transduced with CAR19 that survived the manufacturing process. This leukemic clone evaded CTL019 detection via downregulation of the target antigen in a cell autonomous fashion [78]. Recently, some promising studies investigated the use of CAR $\mathrm{T}$ targeting $\mathrm{CD} 22$ to treat CD19-negative relapses [79-81]. Targeting additional B cell antigens is an active area of investigation.

\section{Conclusions}

With the rapid development of naked monoclonal antibodies, antibody-drug conjugates, bispecific $T$ cell engagers, and adoptive $T$ cell therapies, the era of R/R ALL treatment is fast forwarding. CD19, CD20, CD22, and CD52 are the main markers presented in the majority of B ALL patients and thus are targeted in immunotherapies. With CAR $\mathrm{T}$ therapy moving to the market, achieving higher $\mathrm{CR}$ rates than frontline chemotherapies or even chemotherapies combined with mAbs, the roles of mAbs need to be newly defined. Monoclonal antibodies may still play important roles in induction therapy of ALL due to their availability and relatively safe profile. In the future, immunotherapies may substitute or allow a lower dose of chemotherapy to achieve long-term remission in ALL patients, even in those with poor performance status who are otherwise ineligible for traditional chemotherapy. Despite high remission rate that could be achieved by the aforementioned therapies, relapse still remains as the major problem. As the choices of targeted and immune therapies increase, we must look beyond high remission rates and search for the strategies to prevent relapse and reduce toxicities.

\footnotetext{
Abbreviations

ADC: Antibody-drug conjugate; ADCC: Antibody-dependent cell-mediated cytotoxicity; ALL: Acute lymphoblastic leukemia; BiTE: Bispecific T cell engager; CAR: Chimeric antigen receptor; CDC: Complement-dependent cytotoxicity; CR: Complete remission; CRi: Complete remission with incomplete blood cell count recovery; CRp: Complete remission with incomplete platelet recovery; CRS: Cytokine release syndrome; EFS: Event-free survival; HR: Hazard ratio; HSCT: Hematopoietic stem cell transplantation; INO: Inotuzumab ozogamicin; mAb: Monoclonal antibody; MRD: Minimal residual disease; ORR: Overall response rate; OS: Overall survival; R/R: Refractory/relapsed; RFS: Relapse-free survival
} 


\section{Funding}

This work was jointly supported by the Zhejiang Province Natural Science Funds (LY13H080002) and National Natural Science Funds of China (81470307).

\section{Availability of data and materials}

Data sharing is not applicable to this article as no datasets were generated or analyzed during the current study.

\section{Authors' contributions}

GW, JW, and YZ drafted the manuscript. HH helped to review the manuscript. All authors read and approved the final manuscript.

\section{Ethics approval and consent to participate}

N/A

\section{Consent for publication}

N/A

\section{Competing interests}

The authors declare that they have no competing interests.

\section{Publisher's Note}

Springer Nature remains neutral with regard to jurisdictional claims in published maps and institutional affiliations.

\section{Received: 12 June 2017 Accepted: 7 August 2017}

Published online: 18 August 2017

\section{References}

1. Stock W, Johnson JL, Stone RM, Kolitz JE, Powell BL, Wetzler M, et al. Dose intensification of daunorubicin and cytarabine during treatment of adult acute lymphoblastic leukemia: results of Cancer and Leukemia Group B Study 19802. Cancer. 2013;119:90-8

2. Thomas DA, O'Brien S, Faderl S, Garcia-Manero G, Ferrajoli A, Wierda W, et al. Chemoimmunotherapy with a modified hyper-CVAD and rituximab regimen improves outcome in de novo Philadelphia chromosomenegative precursor B-lineage acute lymphoblastic leukemia. J Clin Oncol. 2010;28:3880-9.

3. Jabbour E, O'Brien S, Ravandi F, Kantarjian H. Monoclonal antibodies in acute lymphoblastic leukemia. Blood. 2015;125:4010-6.

4. O'Brien S, Schiller G, Lister J, Damon L, Goldberg S, Aulitzky W, et al. Highdose vincristine sulfate liposome injection for advanced, relapsed, and refractory adult Philadelphia chromosome-negative acute lymphoblastic leukemia. J Clin Oncol. 2013;31:676-83.

5. Kantarjian H, Gandhi V, Cortes J, Verstovsek S, Du M, Garcia-Manero G, et al. Phase 2 clinical and pharmacologic study of clofarabine in patients with refractory or relapsed acute leukemia. Blood. 2003:102:2379-86.

6. Maury S, Huguet F, Leguay T, Lacombe F, Maynadie M, Girard S, et al. Adverse prognostic significance of CD20 expression in adults with Philadelphia chromosome-negative B-cell precursor acute lymphoblastic leukemia. Haematologica. 2010;95:324-8.

7. Hoelzer D, Walewski J, Dohner H, Viardot A, Hiddemann W, Spiekermann K, et al. Improved outcome of adult Burkitt lymphoma/leukemia with rituximab and chemotherapy: report of a large prospective multicenter trial. Blood. 2014;124:3870-9.

8. Thomas DA, KH JJ, Faderl S, Jabbour E, Konopleva M, et al. Outcomes continue to be favorable for de novo Philadelphia chromosome negative B-lymphoblastic leukemia (ALL) after therapy with hyper-CVAD (with or without rituximab) regimen. Blood. 2012;120(suppl): abstract 3572.

9. Sébastien Maury SC, Xavier T, Dominik H, Thibaut L, Françoise H, Patrice C, et al. Addition of rituximab improves the outcome of adult patients with CD20-positive, Ph-negative, B-cell precursor acute lymphoblastic leukemia (BCP-ALL): results of the randomized Graall-R 2005 study. Blood. 2015; 126(suppl): abstract 1.

10. Maury S, Chevret S, Thomas X, Heim D, Leguay T, Huguet F, et al. Rituximab in B-lineage adult acute lymphoblastic leukemia. N Engl J Med. 2016:375:1044-53.

11. Rai KR. Therapeutic potential of new B cell-targeted agents in the treatment of elderly and unfit patients with chronic lymphocytic leukemia. J Hematol Oncol. 2015 Jul;8:85.
12. Awasthi A, Ayello J, Van de Ven C, Elmacken M, Sabulski A, Barth MJ, et al. Obinutuzumab (GA101) compared to rituximab significantly enhances cel death and antibody-dependent cytotoxicity and improves overall survival against CD20(+) rituximab-sensitive/-resistant Burkitt lymphoma (BL) and precursor B-acute lymphoblastic leukaemia (pre-B-ALL): potential targeted therapy in patients with poor risk CD20(+) BL and pre-B-ALL. Br J Haematol. 2015;171:763-75.

13. Koji SP, Hagop MK, Deborah AT, Maria RK, Guillermo GM, Rebecca G, et al. Phase II Study of the Frontline Hyper-CVAD in Combination with Ofatumumab for Adult Patients (pts) with CD-20 Positive Acute Lymphoblastic Leukemia (ALL). Blood 2015;126(suppl): abstract 1295.

14. Koji SH, Farhad R, Naval D, Tapan MK, Rita BK, Yesid A, et al. Frontline Ofatumumab in Combination with Hyper-CVAD for Adult Patients with CD-20 Positive Acute Lymphoblastic Leukemia (ALL): Interim Result of a Phase II Clinical Trial. Blood. 2016;128(suppl): abstract 2783.

15. Tobinai K, Klein C, Oya N, Fingerle-Rowson G. A Review of Obinutuzumab (GA101), a Novel Type II Anti-CD20 Monoclonal Antibody, for the Treatment of Patients with B-Cell Malignancies. Adv Ther. 2017;34:324-56.

16. Blanc V, Bousseau A, Caron A, Carrez C, Lutz RJ, Lambert JM. SAR3419: an anti-CD19-Maytansinoid Immunoconjugate for the treatment of B-cell malignancies. Clin Cancer Res. 2011;17:6448-58.

17. Younes A, Kim S, Romaguera J, Copeland A, Farial Sde C, Kwak LW, et al. Phase I multidose-escalation study of the anti-CD19 maytansinoid immunoconjugate SAR3419 administered by intravenous infusion every 3 weeks to patients with relapsed/refractory B-cell lymphoma. J Clin Oncol. 2012;30:2776-82

18. Carol H, Szymanska B, Evans K, Boehm I, Houghton PJ, Smith MA, et al. The anti-CD19 antibody-drug conjugate SAR3419 prevents hematolymphoid relapse postinduction therapy in preclinical models of pediatric acute lymphoblastic leukemia. Clin Cancer Res. 2013;19:1795-805.

19. Kantarjian HM, Lioure B, Kim SK, Atallah E, Leguay T, Kelly K, et al. A Phase ॥ Study of Coltuximab Ravtansine (SAR3419) Monotherapy in Patients With Relapsed or Refractory Acute Lymphoblastic Leukemia. Clin Lymphoma Myeloma Leuk. 2016;16:139-45.

20. Amir TF, Tanya MT, Maureen MO, Daniel JD, Bijal DS, Todd MC, et al. Interim analysis of a phase 1 study of the antibody-drug conjugate SGN-CD19A in relapsed or refractory B-lineage acute leukemia and highly aggressive lymphoma. Blood. 2014;124(suppl): abstract 963.

21. Wu J, Fu J, Zhang M, Liu D. Blinatumomab: a bispecific T cell engager (BiTE) antibody against CD19/CD3 for refractory acute lymphoid leukemia. J Hematol Oncol. 2015:8:104.

22. Fan G, Wang Z, Hao M, Li J. Bispecific antibodies and their applications. J Hematol Oncol. 2015:8:130.

23. Klinger M, Brandl C, Zugmaier G, Hijazi Y, Bargou RC, Topp MS, et al Immunopharmacologic response of patients with B-lineage acute lymphoblastic leukemia to continuous infusion of T cell-engaging CD19/ CD3-bispecific BiTE antibody blinatumomab. Blood. 2012;119:6226-33.

24. Topp MS, Kufer P, Gokbuget N, Goebeler M, Klinger M, Neumann S, et al. Targeted therapy with the T-cell-engaging antibody blinatumomab of chemotherapy-refractory minimal residual disease in B-lineage acute lymphoblastic leukemia patients results in high response rate and prolonged leukemia-free survival. J Clin Oncol. 2011;29:2493-8.

25. Le Jeune C, Thomas X. Potential for bispecific T-cell engagers: role of blinatumomab in acute lymphoblastic leukemia. Drug Des Devel Ther. 2016;10:757-65

26. Nicola GH, Massimiliano B, Albrecht R, Carlos G, Christoph F, Helmut D, et al. Long-Term Outcomes after Blinatumomab Treatment: Follow-up of a Phase 2 Study in Patients (Pts) with Minimal Residual Disease (MRD) Positive B-Cell Precursor Acute Lymphoblastic Leukemia (ALL). Blood. 2015;126(suppl): abstract 680.

27. Topp MS, Gokbuget N, Zugmaier G, Klappers P, Stelljes M, Neumann S, et al. Phase II trial of the anti-CD19 bispecific T cell-engager blinatumomab shows hematologic and molecular remissions in patients with relapsed or refractory B-precursor acute lymphoblastic leukemia. J Clin Oncol. 2014;32:4134-40.

28. Topp MS, Gokbuget N, Stein AS, Zugmaier G, O'Brien S, Bargou RC, et al. Safety and activity of blinatumomab for adult patients with relapsed or refractory B-precursor acute lymphoblastic leukaemia: a multicentre, single-arm, phase 2 study. Lancet Oncol. 2015;16:57-66.

29. Francis J, Dharmadhikari AV, Sait SN, Deeb G, Wallace PK, Thompson JE, et al. CD19 expression in acute leukemia is not restricted to the cytogenetically aberrant populations. Leuk Lymphoma. 2013;54:1517-20. 
30. Duell J, Dittrich M, Bedke T, Mueller T, Rasche L, Dandekar T, et al. Crucial role of regulatory $T$ cells in predicting the outcome of the $T$ cell engaging antibody blinatumomab in relapsed and refractory B precursor ALL patients. Blood. 2014;124(suppl): abstract 2291.

31. Kohnke T, Krupka C, Tischer J, Knosel T, Subklewe M. Increase of PD-L1 expressing B-precursor ALL cells in a patient resistant to the CD19/CD3bispecific T cell engager antibody blinatumomab. J Hematol Oncol. 2015:8:111.

32. Ma W, Gilligan BM, Yuan J, Li T. Current status and perspectives in translational biomarker research for PD-1/PD-L1 immune checkpoint blockade therapy. J Hematol Oncol. 2016;9:47.

33. Fan D, Li W, Yang Y, Zhang X, Zhang Q, Yan Y, et al. Redirection of CD4+ and CD8+ T lymphocytes via an anti-CD3 $\times$ anti-CD19 bi-specific antibody combined with cytosine arabinoside and the efficient lysis of patientderived B-ALL cells. J Hematol Oncol. 2015 Oct;8:108.

34. Carnahan J, Wang P, Kendall R, Chen C, Hu S, Boone T, et al. Epratuzumab, a humanized monoclonal antibody targeting CD22: characterization of in vitro properties. Clin Cancer Res. 2003;9(suppl):3982s-3990s.

35. Lumb S, Fleischer SJ, Wiedemann A, Daridon C, Maloney A, Shock A, et al. Engagement of CD22 on B cells with the monoclonal antibody epratuzumab stimulates the phosphorylation of upstream inhibitory signals of the B cell receptor. J Cell Commun Signal. 2016;10:143-51.

36. Raetz EA CM, Borowitz MJ. Reinduction chemoimmunotherapy with epratuzumab in relapsed acute lymphoblastic leukemia (ALL) in children adolescents and young adults: results from Children's Oncology Group (COG) study. Blood. 2011;118(suppl): abstract 573.

37. Advani AS, McDonough S, Coutre S, Wood B, Radich J, Mims M, et al. SWOG S0910: a phase 2 trial of clofarabine/cytarabine/epratuzumab for relapsed/ refractory acute lymphocytic leukaemia. Br J Haematol. 2014;165:504-9.

38. Patrice SC, Françoise $\mathrm{H}$, Emmanuel $\mathrm{R}$, Xavier $\mathrm{T}$, Thibaut $\mathrm{L}$, Tony $\mathrm{M}$, et al. Hyper-CVAD plus epratuzumab as salvage regimen for younger relapsed/ refractory CD22+ B acute lymphoblastic leukemia (ALL) patients: results of the Phase 2 Prospective Cheprall Study. Blood. 2016;128(suppl): abstract 4018.

39. Jabbour EJ, Kantarjian H, Eliasson L, Cornelison AM, Marin D. Patient adherence to tyrosine kinase inhibitor therapy in chronic myeloid leukemia. Am J Hematol. 2012;87:687-91.

40. Kantarjian $H$, Thomas $D$, Jorgensen J, Kebriaei $P$, Jabbour E, Rytting M, et al. Results of inotuzumab ozogamicin, a CD22 monoclonal antibody, in refractory and relapsed acute lymphocytic leukemia. Cancer. 2013;119:2728-36.

41. Kantarjian HM, DeAngelo DJ, Stelljes M, Martinelli G, Liedtke M, Stock W, et al. Inotuzumab ozogamicin versus standard therapy for acute lymphoblastic leukemia. N Engl J Med. 2016:375:740-53.

42. Koji SE, Susan MO, Farhad R, Deborah AT, Tapan MK, Guillermo GM, et al. Phase II study of the salvage mini-hyper-CVD in combination with inotuzumab ozogamicin (INO) for adult patients with relapsed/ refractory $(R / R)$ acute lymphoblastic leukemia (ALL). Blood. 2016; 128(suppl): abstract 1606.

43. Koji SE, Susan MO, Farhad R, Deborah AT, Tapan MK, Guillermo GM, et al. Inotuzumab ozogamicin in combination with low-intensity chemotherapy (mini-hyper-CVD) as frontline therapy for older patients with acute lymphoblastic leukemia (ALL): interim result of a phase II clinical trial. blood;128(suppl): abstract 588 .

44. Wendy SB, Gerard L, Ravi V, John CB, Bayard LP, Meir W, et al. Alemtuzumab can be incorporated into front-line therapy of adult acute lymphoblastic leukemia (ALL): final phase I results of a cancer and leukemia group B study (CALGB 10102). Blood. 2009;114(suppl): abstract 838.

45. Gorin NC, Isnard F, Garderet L, Ikhlef S, Corm S, Quesnel B, et al. Administration of alemtuzumab and G-CSF to adults with relapsed or refractory acute lymphoblastic leukemia: results of a phase II study. Eur J Haematol. 2013;91:315-21.

46. Barrett DM, Singh N, Porter DL, Grupp SA, June $\mathrm{CH}$. Chimeric antigen receptor therapy for cancer. Annu Rev Med. 2014;65:333-47.

47. Maus MV, Grupp SA, Porter DL, June CH. Antibody-modified T cells: CARs take the front seat for hematologic malignancies. Blood. 2014;123:2625-35.

48. Brentjens RJ, Santos E, Nikhamin Y, Yeh R, Matsushita M, La Perle K, et al. Genetically targeted $T$ cells eradicate systemic acute lymphoblastic leukemia xenografts. Clin Cancer Res. 2007;13:5426-35.

49. Davila ML, Kloss CC, Gunset G, Sadelain M. CD19 CAR-targeted T cells induce long-term remission and B cell aplasia in an immunocompetent mouse model of B cell acute lymphoblastic leukemia. PLoS One. 2013;8:e61338.
50. Hu Y, Sun J, Wu Z, Yu J, Cui Q, Pu C, et al. Predominant cerebral cytokine release syndrome in CD19-directed chimeric antigen receptor-modified T cell therapy. J Hematol Oncol. 2016;9:70.

51. Maude SL, Frey N, Shaw PA, Aplenc R, Barrett DM, Bunin NJ, et al. Chimeric antigen receptor T cells for sustained remissions in leukemia. N Engl J Med. 2014;371:1507-17.

52. Lee DW, Kochenderfer JN, Stetler-Stevenson M, Cui YK, Delbrook C, Feldman SA, et al. T cells expressing CD19 chimeric antigen receptors for acute lymphoblastic leukaemia in children and young adults: a phase 1 dose-escalation trial. Lancet. 2015;385:517-28.

53. Jae $H$, Park IR, Wang $X$, Yvette $B$, Terence $P$, Halton $E$, et al. Implications of minimal residual disease negative complete remission (MRD-CR) and allogeneic stem cell transplant on safety and clinical outcome of CD19targeted 19-28z CAR modified T cells in adult patients with relapsed, refractory B-cell ALL. Blood. 2015;126(suppl): abstract 682.

54. Lee DW, Yuan CM, Shah NN, Delbrook C, Yates B, Zhang H, et al. Long-Term Outcomes Following CD19 CAR T Cell Therapy for B-ALL Are Superior in Patients Receiving a Fludarabine/Cyclophosphamide Preparative Regimen and Post-CAR Hematopoietic Stem Cell Transplantation. Blood. 2016; 128(suppl): abstract 218

55. Shah B, Sender LS, Lee DW, Castro JE, Wierda WG, Dietz AC, et al. High rates of minimal residual disease-negative (MRD-) complete responses (CR) in adult and pediatric and patients with relapsed/refractory acute lymphoblastic leukemia (R/R ALL) treated with KTE-C19 (anti-CD19 chimeric antigen receptor [CAR] T cells): preliminary results of the ZUMA-3 and ZUMA-4 trials. Blood. 2016;128(suppl): abstract 2803.

56. Grupp SA, Shaw PA, Aplenc R, Barrett DM, Callahan C, Lacey SF, et al. Durable remissions in children with relapsed/refractory ALL treated with $T$ cells engineered with a CD19-targeted chimeric antigen receptor (CTL019). Blood. 2015;126(suppl): abstract 681.

57. Grupp SA, Buechner J, Bittencourt H, Maude SL, Verneris MR, Myers GD, et al. Analysis of a global registration trial of the efficacy and safety of CTL019 in pediatric and young adults with relapsed/refractory acute lymphoblastic leukemia (ALL). Blood. 2016;128(suppl): abstract 221.

58. Maude SL, Boyer MW, Grupp SA, Davies SM, Phillips CL, Verneris MR, et al. Efficacy and safety of CTL019 in the first US phase II multicenter trial in pediatric relapsed/refractory acute lymphoblastic leukemia: results of an interim analysis. Blood. 2016;128(suppl): abstract 2801.

59. Liu J, Zhong JF, Zhang X, Zhang C. Allogeneic CD19-CAR-T cell infusion after allogeneic hematopoietic stem cell transplantation in B cell malignancies. J Hematol Oncol. 2017 Jan;10(1):35.

60. Kochenderfer JN, Dudley ME, Carpenter RO, Kassim SH, Rose JJ, Telford WG, et al. Donor-derived CD19-targeted T cells cause regression of malignancy persisting after allogeneic hematopoietic stem cell transplantation. Blood. 2013:122:4129-39.

61. Cruz CR, Micklethwaite KP, Savoldo B, Ramos CA, Lam S, Ku S, et al. Infusion of donor-derived CD19-redirected virus-specific T cells for B-cell malignancies relapsed after allogeneic stem cell transplant: a phase 1 study, Blood. 2013:122:2965-73.

62. Brudno JN, Somerville RP, Shi V, Rose JJ, Halverson DC, Fowler DH, et al. Allogeneic T cells that express an anti-CD19 chimeric antigen receptor induce remissions of B-cell malignancies that progress after allogeneic hematopoietic stem-cell transplantation without causing graft-versus-host disease. J Clin Oncol. 2016;34:1112-21.

63. Dai H, Wang Y, Lu X, Han W. Chimeric antigen receptors modified T-cells for cancer therapy. J Natl Cancer Inst. 2016;108: djv439. doi: 10.1093/jnci/djv439

64. Smith M, James S, Davila ML, Velardi E, Argyropoulos EV, Gunset G, et al. Murine donor 1928z CAR T cells exert potent graft-versus-lymphoma activity without graft-versus-host-disease. Blood. 2016;128 (suppl): abstract 653.

65. Cai B, Guo M, Wang Y, Zhang Y, Yang J, Guo Y, et al. Co-infusion of haploidentical CD19-chimeric antigen receptor $T$ cells and stem cells achieved full donor engraftment in refractory acute lymphoblastic leukemia. J Hematol Oncol. 2016;9(1):131.

66. Lee DW, Gardner R, Porter DL, Louis CU, Ahmed N, Jensen M, et al. Current concepts in the diagnosis and management of cytokine release syndrome. Blood. 2014:124:188-95.

67. Barrett DM, Teachey DT, Grupp SA. Toxicity management for patients receiving novel T-cell engaging therapies. Curr Opin Pediatr. 2014;26:43-9.

68. Grupp SA, Kalos M, Barrett D, Aplenc R, Porter DL, Rheingold SR, et al. Chimeric antigen receptor-modified $T$ cells for acute lymphoid leukemia. N Engl J Med. 2013;368:1509-18. 
69. Dummy. From CARs to TRUCKs and beyond: safely en route to adoptive T-cell therapy for cancer. EBio Medicine. 2016;14:1-2.

70. Maude SL, Teachey DT, Porter DL, Grupp SA. CD19-targeted chimeric antigen receptor T-cell therapy for acute lymphoblastic leukemia. Blood. 2015;125:4017-23.

71. Gardner R, Smithers H, Leger K, Annesley CE, Summers C, Brown C, et al. CD19CAR T cell products of defined CD4:CD8 composition and transgene expression show prolonged persistence and durable MRD-negative remission in pediatric and young adult B-cell ALL. Blood. 2016;128(suppl): abstract 219.

72. Turtle CJ, Hanafi LA, Berger C, Gooley TA, Cherian S, Hudecek M, et al. CD19 CAR-T cells of defined CD4+:CD8+ composition in adult B cell ALL patients. J Clin Invest. 2016;126:2123-38.

73. Grupp SA, Maude SL, Shaw PA, Aplenc R, Barrett DM, Callahan C, et al. Durable remissions in children with relapsed/refractory ALL treated with $T$ cells engineered with a CD19-targeted chimeric antigen receptor (CTL019). Blood. 2015;126(suppl): abstract 681

74. Maude SL, Rheingold SR, Aplenc R, Teachey DT, Callahan C, Baniewicz D, et al. Efficacy of humanized CD19-targeted chimeric antigen receptor (CAR)-modified T cells in children and young adults with relapsed/refractory acute lymphoblastic leukemia. Blood. 2016;128 (suppl): abstract 217.

75. Corrigan-Curay J, Kiem HP, Baltimore D, O'Reilly M, Brentjens RJ, Cooper L, et al. T-cell immunotherapy: looking forward. Mol Ther. 2014;22:1564-74.

76. Maude SL, Hucks GE, Seif AE, Talekar MK, Teachey DT, Baniewicz D, et al. The effect of pembrolizumab in combination with CD19-targeted chimeric antigen receptor (CAR) T cells in relapsed acute lymphoblastic leukemia (ALL). J Clin Oncol. 2017;35(suppl): abstract 103.

77. Gill S, Frey NV, Hexner EO, Lacey SF, Melenhorst JJ, Byrd JC, et al. CD19 CAR-T cells combined with ibrutinib to induce complete remission in CLL. J Clin Oncol. 2017;35(suppl): abstract 7509.

78. Lacey SF, Xu J, Ruella M. Cars in leukemia: relapse with antigen-negative leukemia originating from a single B cell expressing the leukemia-targeting CAR. Blood 2016, 128 (suppl): abstract 281;

79. Long AH, Haso WM, Orentas RJ. Lessons learned from a highly-active CD22-specific chimeric antigen receptor. Oncoimmunology. 2013;2:e23621.

80. Haso W, Lee DW, Shah NN, Stetler-Stevenson M, Yuan CM, Pastan IH, et al. Anti-CD22-chimeric antigen receptors targeting B-cell precursor acute lymphoblastic leukemia. Blood. 2013;121:1165-74.

81. Shah nn, Yuan CM, Shalabi H, Yates B, Delbrook C, Zhang L, et al. Minimal residual disease negative complete remissions following anti-CD22 chimeric antigen receptor (CAR) in children and young adults with relapsed/refractory acute lymphoblastic leukemia (ALL). Blood. 2016;128(suppl): abstract 650.

\section{Submit your next manuscript to BioMed Central and we will help you at every step:}

- We accept pre-submission inquiries

- Our selector tool helps you to find the most relevant journal

- We provide round the clock customer support

- Convenient online submission

- Thorough peer review

- Inclusion in PubMed and all major indexing services

- Maximum visibility for your research

Submit your manuscript at www.biomedcentral.com/submit

) Biomed Central 